\title{
CORPORATE FIDUCIARY DOCTRINE IN THE CONTEXT OF PARENT-SUBSIDIARY RELATIONS*
}

ONE of the most confused areas of corporation law is the set of doctrines requiring parent corporations to be "fair" in their dealings with their subsidiaries, insofar as those dealings affect the interests of minority shareholders and creditors of the subsidiaries. ${ }^{1}$ The fairness of such parent-subsidiary transactions is determined in accordance with corporate fiduciary doctrine, the body of law purporting to impose the duties of a trustee on corporate controlgroups. ${ }^{2}$ To date, there has been no explicit recognition of the parent-stubsidiary relationship as a distinct doctrinal category; the parent, as such, owes no special fiduciary duty. Rather, the rules applied to parent-stubsidiary controversies are those defining the duties of majority shareholders in their exercise of control over corporate affairs, and of directors in their conduct of relations with other companies in which they are interested. ${ }^{3}$ The confusion attending

*Case v. New York Cent. R.R., 19 App. Div. 2d 383, 243 N.Y.S.2d 620 (1963), revcrsing 232 N.Y.S.2d 702 (1962).

1. See Note, The Fairness Test of Corporate Contracts with Intercsted Dircctors, 61 HARv. L. REv. 335, 337 (1948).

For analytical purposes, such parent-subsidiary relationships can be recognized when a single group of individuals controls more than one corporation whose economic and financial operations are coordinated, whether such control is exercised through predominant voting control by the individuals, by one corporation over others, by interlocking boards of directors or by a combination of these methods.

2. The corporate fiduciary concept has received considerable treatment from legal commentators. For some of the more influential and useful interpretations, see BerLE \& MEANS, The Modern Corporation and Private Property (1932); Berle, Corporate Pouters as Powers in Trust, 44 HaRv. L. Rev. 1049 (1931) ; Berle, For Whom Corporate Managers are Trustees: $A$ Note, 45 Harv. L. REv. 1365 (1932); Rohrlich, Stits in Equily by Minority Stockholders as a Means of Corporate Control, 81 U. PA. L. Rev. 692 (1933); Rostow, To Whom and for What Ends Is Corporate Management Responsible? Tur Corporation IN Modern Society 46 (Mason ed. 1959); Bayne, The Fiduciary Duty of Management - The Concept in the Courts, 35 U. DET. L.J. 561 (1958).

For a treatment of the distinctions between the fiduciary concept in its original context and in its application to corporation law, see 1 Hornstein, Corporation Law and PuAcTICE $\S 431$ (1959).

3. It was once unclear whether the same such duties could be imposed on a majority shareholder as were required of a director. Berle, supra note 2, at 1049, 1067. Geller v. Transamerica Corp., 63 F. Supp. 248, 251 (D. Del.) (dictum), aff'd, 151 F.2d 534 (3d Cir. 1945). Indeed, some commentators have even recently argued that the idealized concept of the shareholder seems inconsistent with fiduciary status. Comment, 54 Mrcir. L. REV. 971, 976 (1956). But, in parent-subsidiary cases, conceptual distinctions have not prevented the courts from moving to thwart majority shareholders who do "in fact" exercise control and manifest too disturbing an indifference to the interests of non-controlling shareholders or creditors. Southern Pacific Co. v. Bogert, 250 U.S. 483, 487-88 (1919) ; Farmers' Loan \& Trust Co. v. N.Y. \& No. Ry., 150 N.Y. 410, 431, 44 N.E. 1043, 1049 (1896) ; Zahu v. Transamerica Corp., 162 F.2d 36 (3d Cir. 1947). It makes no practical or legal difference 
application of these rules may be traced to three sources. First, the variety of rules which compete for the attention of courts and lawyers has prevented the development of a consistent scheme of decisions. Second, the applicable doctrines themselves impede analysis, for they are derived from concepts which ignore the structure and purpose of the usual parent-subsidiary relationship; as a result the rules have too often served, not as guides to a meaningful definition of fairness, but as formulae repeated mechanically in rationalizing intuitive conclusions. ${ }^{4}$ Finally, the rules were originated earlier in this century; subsequently, relations within corporate systems have become characterized by a high degree of economic integration, and rapacity on the part of corporate control-groups has become less pronounced. Because the prevailing standards of parent-subsidiary fairness have not been altered to reflect these changes, their logic seems to lead to unsatisfactory results.

A troublesome case pending on appeal before the New York Court of Appeals, Case v. Newe York Central R.R., dramatizes the difficulties confronting the law in this area. Suit was brought by minority shareholders in a Central subsidiary, seeking to rescind an agreement between the two linked corporations entered into by the Central management in their capacity as directors of both. The agreement provided for the allocation to the parent company of almost all the tax savings realized from the consolidation of the tax returns of the two companies. ${ }^{7}$ The trial court found the allocation to be fair. ${ }^{8}$ The Appellate Division, despite a strong dissent, reached the opposite result. The majority justified its "clear" conviction that the allocation was not fair by reference to the disparity between the controverted transaction and one which would have been reached by "independent bargainers."

The Appellate Division's approach to the challenged transaction typifies the prevailing method of deciding parent-subsidiary controversies. In seeking standards of fairness, the courts have most frequently drawn upon the concept of the model contractual transaction - an agreement, isolated from any ongoing relationship, reached by independent parties. This concept has impelled the measurement of the fairness of intercorporate dealings in terms which refer to arm's length relationship, bargaining process, and adequacy of con-

whether the nominal defendant in a given case is the majority sharcholder of the complaining subsidiary or the directors appointed to assume ostensible management thereof. Compare Geddes v. Anaconda Copper Mining Co., 250 U.S. 590, 599 (1921), wish Seventeen Stone Corp. v. General Telephone Co., 204 F. Supp. 885, 888 (S.D.N.Y. 1962).

4. Ward, Some Notes on Transactions Involving Interested and Interlocking Directors in Peinusylvania, 23 Texrple L.Q. 107, 112 (1949).

5. For elaboration of this point, see notes $41-47$ infra and accompanying text.

6. 19 App. Div. 2d 383, 243 N.Y.S.2d 620 (1963), reversing 232 N.Y.S.2d 702 (1962).

7. The majority opinion in the Appellate Division calculated the percentage taken by Central as better than $98.5 \%$, as opposed to the $80 \%$ Central would have received in dividends as majority shareholder of the subsidiary, had the latter "kept" all the savings to itself. 19 App. Div. 2d 383, 385, 243 N.Y.S.2d 620, 622.

8. 232 N.Y.S.2d 702 (1962).

9. 19 App. Div. 2d 383, 386, 243 N.Y.S.2d 620, 623 . 
sideration. ${ }^{10}$ The principal doctrine derived from the concept of the model contractual transaction is:

... whether or not under all the circumstances the transaction carries the earmarks of an arm's length bargain. If it does not, equity will set it aside. ${ }^{11}$

In fact, the transactions disputed in parent-subsidiary cases are neither bargains, nor, much less, are they conducted at arm's length; rather, they are the product of decisions made by the single group in control of both corporam tions. Thus, the basic premise of the arm's length test - two independent parties with approximate bargaining equality - is at odds with the reality of the parent-subsidiary relationship, and ignores the economic leverage and decision making power possessed by the control group. The question presented by each case is whether the result of the imposed decision was fair to the plaintiff, a question not to be equated with that posed by the arm's length test: whether that result would have been achieved within the structure of an arm's length relationship and via a process of bargaining. ${ }^{12}$ As a consequence of these conceptual inadequacies, the rule has not functioned as a genuine test of the fairness of dealings between parent and subsidiary corporations. Rather, because of its inherent bias in favor of the dominated unit in intercorporate transactions, it has served principally as a means of rationalizing decisions against defendant control-groups. ${ }^{13}$

On the other hand, the inadequacy of the arm's length test has also permitted its manipulation for the advantage of defendants. Thus, in situations where it is impossible to state precisely what the result of an arm's length agreement would have been, some courts have used this fact as a basis for dismissing plaintiff's claim. ${ }^{14}$ Although the alleged impossibility of proof may

10. See, e.g., Pepper v. Litton, 308 U.S. 295, 306-07 (1939); Geddes v. Anaconda Copper Mining Co., 254 U.S. 590, 599 (1921); Austrian v. Williams, 103 F. Supp. 64, 75 (S.D.N.Y. 1952) ; Shlensky v. South Parkway Bldg. Corp. 19 Ill. 2d 268, 283, 166 N.E.2d 793, 801 (1960), and cases cited therein; Ripley v. International Rys., 8 App. Div. 2d 310, 319, 188 N.Y.S.2d 62, 72 (1959), aff'd, 8 N.Y.2d 430, 209 N.Y.S.2d 289, 171 N.E.2d 443 (1960).

11. Pepper v. Litton, 308 U.S. 295, 306-07 (1939) (Douglas, J.).

12. As used in this Note, the term "result" means the distribution of the proceds among the parties to a transaction. "Structure" refers to the relation of power and function between the parties conditioning the transaction - whether they face each other from positions of mutual independence, or whether and to what extent and for what purposes power is vested predominantly in the hands of one. "Process" signifies the manner in which the transaction is guided to its close.

13. See cases cited in note 10 sutpra.

14. Western Pac. R.R. Corp. v. Western Pac. R.R. Co., 206 F.2d 495, 499-500 (9th Cir. 1953). For an attempt to rationalize the doctrine for purposes of solving this problcm, see Ewen v. Peoria \& E. Ry., 78 F. Supp. 312 (S.D.N.Y. 1948) (L. Hand, I.). In the Western Pacific case, supra, the court affirmed dismissal of a claim involving the appro. priation of tax-savings by a controlling company, similar to the claim in Case v. Nezu York Central. The Ninth Circuit decision, handed down following remand from the Supreme Court for rehearing of a procedural issue, controverted remarks made by Justice 
be the result of mere absence of objective standards, such as market value, on which to base a determination of adequacy of consideration, it is more likely that courts find it impossible to picture independent parties engaging in the types of transactions typical in the complex scheme of parent-subsidiary relations. ${ }^{15}$

A second test of fairness derived from the model of the contractual transaction is that of fraud, the presence of which is considered ground for the invalidation of a contract. ${ }^{16}$ Crucial as this doctrine may be to the law of contract, it is often inapposite in the type of situations arising in parent-subsidiary cases. While the concept of fraud denotes deception, where there is but one genuine actor - the group controlling both parent and subsidiary - there can be no one to deceive or to influence to act to his own detriment. Generally, the degree to which the defendant has disclosed material facts or purposes pertinent to the transaction is not at issue - it is the use of his monopoly of power, possession of which makes concealment unnecessary for the attainment of his ends. ${ }^{17}$ Since fraud is as unlikely to appear in the facts of a parentsubsidiary dispute as is a genuine arm's length bargain, invocation of the rule that contracts cannot be set aside unless "actual" fraud is alleged and proven places in plaintiff's path an obstacle which is literally insurmountable. Consequently, this rule has served as a convenient instrument for courts vishing to uphold challenged transactions. ${ }^{18}$

Jackson, dissenting. He had justified his conclusion that the claim ought to be allowed via arm's length analysis: "Each corporation ... had a bargaining position. The stakes vere high. Neither could win them alone, although each had an indispensable something that the other was without... Each of these parties had but one key, and how can it be sail that the holder of the other key had nothing worth bargaining for?" Western Pac RR. Corp. v. Western Pac. R.R. Co., 345 U.S. 247, 277 (1953) (dissenting opinion). To this contention, the collective wisdom of the Ninth Circuit, sitting $m$ banc, demurred, and turned Justice Jackson's argument on its head: "How could the court remake the contract for the parties? How could this court ... determine what fair arm's length bargaining would probably have yielded .... Such activity is a matter of business administration and is not a judicial function." 206 F.2d 495, 499-500.

15. See, e.g., the transaction challenged in the Western Pacific case, supra note 14; or Ewen v. Peoria \& E. Ry., 78 F. Supp. 312 (S.D.N.Y. 1948). See also Case v. New York Central R.R, 19 App. Div. 2d 383, 388, 243 N.Y.S.2d 620, 627 (1963) (dissenting opinion).

16. Skelly v. Dockweiler, 75 F. Supp. 11, 14 (S.D. Cal. 1947); Briggs v. Scripps, 13 Cal. App. 2d 43, 45, 56 P.2d 277, 278 (1936); Eighteen Fulton St. Corp. v. Appel, 272 App. Div. 602, 603, 74 N.Y.S.2d 17, 18 (1947); Barnes v. Atlantic Cement Prods., Ine, 39 N.Y.S.2d 699, 727 (Sup. Ct. 1942).

17. While actual fraud is assuredly possible within the context of a parent-subsidiary relationship, it seems rarely to occur in fact. Reference to the concept of fraud in parentsubsidiary has generally been beside the point.

18. Thus, in Skelly v. Dockweiler, 75 F. Supp. 11 (S.D. Cal. 1947), minority shareholders sued to enjoin a proposed merger of the corporation in which they held an interest with another corporation controlled by the majority shareholder. The court apparently disapproved of the suspected intentions of the plaintiffs, referring unfavorably at one point to their failure to allege willingness on their part to sell their shares at a fair price, in 
Where a decision for the plaintiff seems called for, however, precedent requiring proof of "actual" fraud presents grave logical difficulties. Courts have avoided these difficulties via the doctrine of "constructive" fraud. ${ }^{10}$ While courts have proposed various definitions of this term, ${ }^{20}$ the results fail to fall into a discernible pattern. ${ }^{21}$ The term has been characterized as "inept," and at least one court has been frank enough to observe that it is nothing more than a means of finding some way of imposing the liabilities attendant t1pon a finding of fraud where there is no fraud in fact. ${ }^{23}$

Another concept derived from contract law often applied to parent-subsidiary cases is the notion of good faith. ${ }^{24}$ Good faith, like fraud, refers to the posture of a party engaged in the process of bargaining. ${ }^{25}$ Similarly, it signifies in part, the truthfulness of disclosures of purpose, and even more than fraud seems to impart exclusively subjective connotations. The term is also used

order to allow the consummation of the merger. The court denied the injunction, reasoning that transactions between corporations could not be set aside unless actual fratd were found, that no fraud was alleged or proven, and that, therefore, the proposed merger must go through. Id. at 14 .

19. Lytle v. Fulotka, 106 Okla. 86, 90, 233 Pac. 459, 460 (1925); Seagrave Corp. v. Mount. 212 F.2d 389, 397 (6th Cir. 1954); Food Machinery Corp. v. Moon, 165 S.W.2d 773, 775 (Tex. Civ. App. 1942).

20. See Winger v. Chicago City Bank \& Trust Co., 394 I11. 94, 108, 67 N.E.2d 265, 275 (1946) ; Olitkowski v. St. Casimer's Sav. \& Loan Ass'n, 302 Mich. 303, 308-09, 4 N.W.2d 664, 667 (1942); Appeal of Eastman, 135 Me. 233, 236, 194 At1. 586, 588 (1937); Epstein v. United States, 174 F.2d 754, 766 (6th Cir. 1949).

21. The difficulty of gleaning from the various applications of the term a workable definition may be gauged by reference to the black-letter attempt of Corpus Jurus SEcunDUM: "Constructive fraud is most frequently found in a breach of duty arising out of a fiduciary or confidential relationship; but the authorities are not entirely harmonious as to when, for this purpose, a fiduciary or confidential relationship exists, and the rules laid down for determining the question are not definite." 37 C.J.S. Frand \& 2(c) (1943).

22. Charleroi Lumber Co. v. Bentleyville Borough School Dist., 334 Pa. 424, 432, 6 A.2d 88, 91 (1939).

23. In re Bowen, 151 F.2d 690, 691 (3d Cir. 1945) (Goodrich, J.) :

[W]e said that fraud might be shown to void the release, going on what secmed to us ... the almost universal analogy as to the effect of fratd in transactions generally.

Proof having failed to show actual fraud ...., we are now asked to say that something else will do. That something else is made to sound like fraud by putting the word "constructive" in front of it. No better illustration could be found of the dangers involved in the slippery use of language. Constructive fraud, of course, is not fraud at all as both lawyers and laymen know and understand the term, but conduct which the courts regard as liability creating and which, therefore, has some of the consequences which actual fraud has.

24. See, e.g., Austrian v. Williams, 103 F. Supp. 64, 75 (S.D.N.Y. 1952); Pepper v. Litton, 308 U.S. 295, 306 (1939) ; Acme Mines Dev. Co. v. Clawson, 66 Utah 103, 114-15, 240 Pac. 165, 169-70 (1925).

25. In the context of the bargaining process, good faith has always meant the contrary of fraudulent intent. See, e.g., Tapia v. Williams, 172 Ala. 18, 29, 54 So. 613,617 (1911); Stark v. Starr, 22 Fed. Cas. 1084, 1088 (1870); Docter v. Furch, 91 Wis. 464, 476, 65 N.W. 161, 164 (1895). 
in reference to various types of otherwise undefined conduct, especially observance of relevant trade practices. ${ }^{26}$ To the extent that historical and logical ties bind the concept of good faith to the law of contract, the notion is conceptually unsuited to a situation where there is no bargaining. In the same vein, since disclosure is rarely an issue in parent-subsidiary cases, application of good faith principles requiring disclosure is both unnecessary and misleading. Moreover, its emphasis on subjective motivation makes the existence or nonexistence of the concept difficult or incapable of demonstration. ${ }^{27}$ For these reasons, and because of its utility as a catch-all, the concept of good faith has been employed in the case-law of parent-subsidiary disputes chiefly as a make-weight to reinforce a court's disapproval of defendant's objectives, particularly the acquisition or extension of corporate power, or the total elimination of minority interests in the subsidiary. ${ }^{28}$

Finally, the bankruptcy of analysis based on the model of the contractual transaction is manifested by the rule, stated emphatically in the leading cases in the field, that the burden of proving the fairness of a challenged transaction is on the defendants. ${ }^{29}$ The emphasis placed upon this procedural consideration has elevated it to the status of a substantive rule of law. Its effect is not merely to shift the burden of going forward with the evidence in a procedural sense, ${ }^{30}$ but to place on the defendant the difficult task of constructing a rationale which will satisfy the trier of fact that the transaction was fair. ${ }^{31}$

26. See, e.g., UnIForar Coararercial Code § 2-103(1) (b).

27. Cf. Note, 61 Harv. L. Rev. 335,340 (1948).

28. See notes 46 and 49 infra and accompanying text. See, c.g. Pepper v. Litton, 303 U.S. 295 (1939) ; Farmers' Loan \& Trust Co. v. New York \& N.R.R, 150 N.Y. 410, 44 N.E. 1043 (1896). Conversely, the term is employed in justifying dismissal of a claim challenging conduct demonstrating objectives less far-reaching and methods less brazen. See, e.g., Acme Mines Dev. Co. v. Clawson, 66 Utah 103, 114-15, 240 Pac. 165, 169-70 (1925).

29. Geddes v. Anaconda Copper Mining Co., 254 U.S. 590, 599 (1921); Pepper v. Litton, 308 U.S. 295, 306 (1939). Indeed, this rule is the principal legal proposition for which these cases are said to stand. See, e.g., Shlensky v. South Parkway Bldg. Corp., 19 Ill. 2d 268, 282, 166 N.E.2d 793, 801 (1960); Annot., 33 A.L.R.2d 1060, 1072-73 (1954), and cases cited therein.

30. Normally, the burden of proof falls on the party desiring to have the action taken by the court, i.e., in almost all cases, the plaintiff. Shifting the burden to the defendant can only be said to serve a genuinely procedural function when it operates to distribute equitably the task of introducing evidence of facts relevant to the claim. Thus, the burden is shifted to the defendant where relevant information is exclusively within his knowledge or possession, or where the plaintiff has a negative assertion to prove, such as non-performance of a condition in a suit for breach of contract. See 9 Wigarore, Evidence $\$ 2486$ (3d ed. 1940).

31. For discussion of the analytical problems presented by the Goddes rule as to the allocation of the burden of proof in corporate fiduciary cases, see Even v. Peoria \& E Ry., 78 F. Supp. 312, 317 (S.D.N.Y. 1948). There are cases which purport to hold, contrary to the Geddes rule, that the plaintiff has the burden of proof. But see Ward, supra note 4, at 116. Other cases hold that, before the burden can be shifted to the defendant, prima facie evidence of unfairness must be shown by the plaintiff. See, e.g., Mayflower Hotel Stock- 
When applied in conjunction with the elusive substantive rules used to mersure fairness, allocation of the burden effectively decides the case, and relieves the court of the necessity of articulating its reasons for finding for plaintiff.

Similar shortcomings have attended the application of the second principal concept to which the courts have referred in testing the fairness of parentsubsidiary transactions - the concept of the model corporate structure outlined by most corporation statutes. This concept presupposes that the groups within the corporation actually conform to the theoretical roles and relationships assigned them by statute. Thus, directors are envisaged as the independent managers of the corporation responsible for broad policy decisions and answerable to the shareholders, who, in turn, are seen as a distinct group capable of exercising effective supervision. ${ }^{32}$ The most direct application of this model is found in the set of rules emphasizing the degree to which procedural formalities have been observed: was the challenged transaction approved by a disinterested majority of the board of directors ?33 was the decision made at a meeting legitimated by a disinterested quorum ${ }^{34}$ was the decision ratified by the shareholders ?35 To the extent that the actual structure of power within the corporation deviates from these conceptual norms, the logic of the doctrines derived from the statutory model loses its efficacy. Since claims of breach of fiduciary duty arise only in situations where a single group is majority shareholder of both corporations, master of the directors and officers, and, less frequently, creditor as well, the illogic of applying such doctrines to the parent-subsidiary disputes is apparent. ${ }^{36}$ Indeed, the inappropriateness of these rules is so patent that the use of rules derived from statutory structural and procedural norms has been increasingly rare and may be considered of diminishing import. ${ }^{37}$

holders Protective Comm. v. Mayflower Hotel Corp., 721 F. Supp. 231 (D.D.C. 1947). The impact of the weight given to allocation of the burden of proof on the quality of the arguments of counsel for the parties is reflected by the remarks of Judge Stetuer, dissenting in Case v. New York Central:

A great part of the energy expended by counsel was in part an effort to show that the burden of proving fairness or unfairness was on the other side, and cach having established (at least to his own satisfaction) that it was on his adversary, cach relied on the fact that it was impossible for the another to make the proof.

19 App. Div. 2d 383, 390, 243 N.Y.S.2d 620, 627 (1963) (dissenting opinion).

32. The same presuppositions are given critical analysis with respect to doctrinal cmphasis on shareholders' voting rights in Chayes, The Modern Corporation and the Rule of Law, in MAson, op. cit. supra note 2, at 40, and in Manning, Book Revicz, 67 Yare L.J. 1478 (1958).

33. Twin-Lick Oil Co. v. Marbury, 91 U.S. 587 (1876) ; Cowell v. McMillin, 177 Fed. 25 (9th Cir. 1910).

34. See, e.g., Parsons v. Tacoma Smelting \& Ref. Co., 25 Wash. 492, 65 Pac. 765 (1901).

35. See, e.g., Gamble v. Queens County Water Co., 123 N.Y. 91, 25 N.E. 201 (1890).

36. For an example of the use of creditor status to destroy the interests of minority shareholders in a subsidiary, see Farmers' Loan \& Trust Co. v. New York \& No. Ry., 150 N.Y. 410,44 N.E. 1043 (1896).

37. Compliance with such requirements as to the composition of the board of directors, the quorum, and ratification by the shareholders will not immunize a transaction the results 
A conceptual cousin of these dying doctrines, however, retains legal vitality. This approach, denominated as the business judgment rule, concentrates, not on formal decisional procedures, but on an idealized picture of the role of the management group and on the cast of mind which marks their approach to that task. The rule states that courts will not interfere in the management of corporations and will not upset decisions made by directors or officers as long as the latter act on the basis of honest business judgment. ${ }^{38}$ Underlying the rule are the assumptions that the direction of a corporation is a job requiring expertise and experience and that courts making after-the-fact judgments are apt to overlook the difficulties involved in the actual process of decision. ${ }^{50}$

Although these assumptions are not inaccurate in themselves, they do not, without more, constitute a workable basis for a rule of decision, for they yield no means of making distinctions; to state merely that courts should rarely interfere gives no clue whatsoever as to when they should or should not interfere. The requirement of honesty is designated as the element on which the distinction rests. But, being a subjective element, it suffers from the same definitional and evidentiary infirmities as good faith $:^{10}$ and, referring to the factor of disclosure, it is generally as irrelevant to the real issues in parent-subsidiary cases as are concepts of fraud.\$1 As a result of these defects, the business judgment rule has been used in the case-law principally as a means of escaping, rather than aiding, analysis.

In some recent cases, the business judgment rule has served courts discomfited with the arm's length test where its imperatives seemed to compel the wrong result. ${ }^{42}$ When these cases are examined with reference to their hisof which are deemed unfair. See Remillard Brick $C_{0}$. v. Remillard-Dandini Co, 109 Cal. App. 2d 405, 241 P.2d 66 (1952) ; Kennerson v. Burbank Amusement Co., 120 Cal. App. 2d 157, 260 P.2d 823 (1953); Wiseman v. United Dairies, Inc, 324 Mich. 473, 37 N.W.2d 174 (1949). Still, compliance or non-compliance with such requirements is not without weight in some courts. See Lewis v. Hat Corp. of Am., 38 Del. Ch. 313, 150 A.2d 750 (1959) ; Colorado Management Corp. v. American Founders Life Ins. Co, 145 Colo. 413, 359 P.2d 665 (1961). An assessment of the remaining effect of such rules appears in 1 Hornstein, Corporation Law and Practice $\$ 439$ (1959).

38. See, e.g., Everett v. Phillips, 288 N.Y. 227, 43 N.E.2d 1S (1942), discussed in note 41 infra; Piccard v. Sperry Corp., 48 F. Supp. 465, 467 (S.D.N.Y. 1943); Price v. Standard Oil Co., 55 N.Y.S.2d 890, 896 (Sup Ct. 1945).

39. Marony v. Applegate, 266 App. Div. 412, 426, 42 N.Y.S.2d 768, 782-83 (1943).

40. See notes $24-26$ sipra and accompanying text.

41. See text following note 17 sipra.

42. For example, in the case of Everett v. Phillips, 288 N.Y. 227, 43 N.E.2d 18 (1942), a dispute arising out of the financial woes plaguing the Long Island Lighting Co. system during the depression years, the court applied the business judgment rule in deciding against plaintiff's claim. The particular transaction challenged was a series of short-term "loans" made by the partially controlled Empire Power Corporation to the parent, Long Island; as the loans had fallen due, they were not repaid, and the directors of the creditor-subsidiary, also the directors and sole shareholders of the debtor-parent, renewed them. The court, speaking through Judge Lehman, conceded that other alternatives had been open to the Empire directors which would have been more consistent with the concept of an in- 
torical context and to the business facts giving rise to the legal dispute, they illuminate the new developments which have made some courts unwilling to follow out the logic of arm's length analysis. The first of these factors is the development of economic integration of an extensive and refined degree, as opposed to mere legal or managerial control. Such integration has tended to magnify the structural inadequacies of the arm's length test. ${ }^{43}$ The use of common executive staffs and identical equipment and facilities often proceeds to a point where the legal distinction between parent and stibsidiary becomes largely irrelevant to the business operations of the system. ${ }^{44}$ And the complex and continuing relationships generated by the economic integration within such a system make it often misleading to test the fairness of an isolated legal transaction without reference to its context. ${ }^{45}$ Under such conditions, application of arm's length principles may end in frustrating the objectives which originally led both parties to enter into the relationship - pooling of capital, centralization of management, division of function, and other cconomies of scale - which promise benefits, not only to the parties interested in the two corporations, but to the national economy as well.

dividual entity protecting its interests. The court's dismissal of plaintiff's claim turned on its application of the business judgment rule:

... however high may be the standard of fidelity to duty which the courts of this State may exact, errors of judgment by directors do not alone stffice to demonstrate lack of fidelity....

There are many matters disclosed by the record which cast doubt upon the prudence, wisdom, and concern for the public interest shown by these directors. . . .

But the defendants can be charged with no wrong to the corporation ... . without proof that they willfully failed to protect the interests of the Empire Power Corporation....

Id. at 232-37.

43. In Marony v. Applegate, 266 App. Div. 412, 422, 42 N.Y.S.2d 768, 779 (1943), the court rested its choice of the business judgment rule on the existence of "such circumstances," although it did not articulate the logic behind that decision. But see Chelrob v. Barrett, 293 N.Y. 442, 460-61, 57 N.E.2d 825, 834 (1944).

44. See Marony v. Applegate, supra note 43, at 422, 42 N.Y.S.2d at 778-79; Espach v. Nassau \& Suffolk Lighting Co., 293 N.Y. 463, 466, 57 N.E.2d 835, 836 (1944).

45. Thus in Ripley v. International Rys. of Cent. Am., 8 App. Div. 2d 310, 319-20, 188 N.Y.S.2d 62, 73-74 (1959), defendant United Fruit Co. argued that

the contracts are fair when not only the tariff rates are considered, but when all of the other relevant factors are weighted - such as, essential financing, use of railroad equipment, availability of connecting carrier facilities, reduction of terminal services, assurances of stable and substantial traffic volume. . . .

The court gave extensive concern to this argument, but purported to reject it in affirming the referee's award of damages to plaintiff subsidiary. However, in refusing to award at much higher measure of damages based on comparison with the rates of other carricrs, the court, by implication, does appear to have given these factors some weight.

In Austrian v. Williams, 103 F. Supp. 64, 103, 105 (S.D.N.Y. 1952), Judge Weinfeld managed to fit consideration of analogous factors into application of the arm's length test. He decided that if an independent corporation had found itself placed in an analogous relationship, it could have accepted the terms of the challenged transaction. 
In addition to the consequences of economic integration, recent parentsubsidiary cases have reflected the changes in the behavior of corporate control groups effected by a maturing economy and the pressure of government regulation. Officers and directors charged with breach of fiduciary duties by minority shareholders in subsidiary corporations are frequently no longer guilty of attempting to extend their control or to eliminate totally the interests of minority shareholders or of creditors. ${ }^{16}$ While defendants may be less concerned with the interests of minority shareholders than would be an independent representative, their conduct is not capable of generating the sort of intense indignation from the bench and the law schools which shaped much of the current fiduciary doctrine. ${ }^{47}$ Contemporary defendants have tended to be professional managers given erroneous counsel as to the limits within which they could legally maximize the parent company's share of the fruits of economic integration. ${ }^{48}$ In such cases, the objectives of management have tended to relate to the allocation of costs and benefits between the corporate units forming the system and the parties interested therein. ${ }^{10}$

In general, the response of the courts to these changes has been disappointing. Escape from the strictures of the arm's length test has been achieved predominantly by manipulation of the traditional corporate fiduciary doctrines and their conceptual bases. ${ }^{50}$ Several courts have, however, adopted an ap-

46. Transactions motivated by such objectives amount to what is known as a "ireczeout," a phenomenon less apparent today than in the 1920's and before. Professor Berle, in reexamining corporate practices recently, conceded that

the administrators of the corporations may have seen some light (possibly somewhere on the road to the Pecora Investigation or the Securities \& Exchange Commission) since 1933. The principles and practice of big business in 1959 seem to me to be considerably more responsible, more perceptive, and (in plain English) more honest than they were in 1929.

The Corporation in Modern Soctety xiii (Mason ed. 1959).

47. Compare the attitude evinced by the contributors to MIASON, op. cit. supra note 46 , especially Rostow, Chayes, and Berle, with Berle vintage 1932, supra note 2, and the remarks of Mr. Justice Stone in The Public Influence of the Bar, 48 HARv. L. Rev. 1, 9 (1934).

48. This, perhaps, is one reason why courts are so anxious to ayoid attaching to director defendants subjective labels, such as "bad faith" or "dishonesty," which connote "frcezeout" objectives. See, e.g., Chelrob, Inc. v. Barrett, 293 N.Y. 442, 448, 450, 57 N.E.2d 825, 833 (1944) ; Everett v. Phillips, 288 N.Y. 227, 43 N.E.2d 18 (1942), discussed in note 42 supra.

49. Compare, e.g., Case v. New York Central R.R, 19 App. Div. 2d 383, 243 N.Y.S.2d 620 (1963), and Ewen v. Peoria \& E. Ry., 78 F. Supp. 312 (S.D.N.Y. 1948), wilh Farmers' Loan \& Trust Co. v. New York \& N.R.R., 150 N.Y. 410, 43 N.E. 1043 (1896), and Pepper v. Litton, 308 U.S. 295 (1939).

50. See examples and discussion, notes $14-15,18,38-43$ stpra and accompanying text. Another more imaginative use of the arm's length test is the argument that, had the subsidiary been independent in fact, its economic weakness would have precluded its obtaining better terms. Ewen v. Peoria \& E. Ry., 78 F. Supp. 312, 337 (1948). Still another, no less unfortunate, innovation is the rule that, where the subsidiary has sustained a "profit," no 
proach which can be viewed as a step, at least in the direction of relating legal doctrine to business realities. This method utilizes a provision found in the corporate charter of most large modern corporations, authorizing the corporation to deal with other companies in which its directors and officers are interested. ${ }^{51}$ The source of this approach appears to be the case of Spicgcl $v$. Beacon Participations, Inc.52 In Spiegel, shareholders in a bank subsidiary, the function of which was to provide the parent and its control-group with a vehicle for speculation, sued for restitution of losses incurred by the stbsidiary. The court refused to apply the burden of proof to defendants, and emphasized the authorization clause in the subsidiary corporation's charter. ${ }^{63}$ The court interpreted the clause as

designed to permit interlocking directorates of a broad nature, and to give wide power to each director ... to engage in behalf of the defendant with other corporations and associations ... provided the nature of his interest was disclosed..$^{54}$

The court held that the provision exonerated directors with dual interests from "adverse inferences which might otherwise be drawn against them." suit questioning transactions between the New York Central and a subsidiary, Judge Learned Hand used to similar effect analogous language included in the original agreement signed upon the purchase of the subsidiary by the Central.50 Hand reasoned that the clause "presupposed" that the parent was to "determine the interests of both in those mutual transactions which would constantly arise between the two." "57 Hand also made a serious attempt to formulate new doctrinal concepts explicitly derived from the facts peculiar to sttch integrated systems. Noting that the subsidiary was "part of a single railway system, operated as a constituent unit after the conventional pattern in such cases," he concluded that the arm's length test needed "further analysis" in such a situation. ${ }^{58}$ Rather, said the court, the applicable test ought to be based on the manner in which Central would treat a "wholly owned division,"

matter how slight, and has not suffered a "loss," the challenged transaction must stand. Cleary v. Higley, 154 Misc. 158, 163, 277 N.Y.S. 63, 78 (1934); Espach v. Nassau \& Suffolk Lighting Co., 293 N.Y. 463, 466, 57 N.E.2d 835, 836 (1944). Since there is no qualitative distinction between a "loss" in terms of monetary assets, and the receipt of inadequate consideration in an exchange, the rule is simply not a logical proposition. It is usually ignored in cases where the difference between the value received and the fair valte is very great. See, e.g., Ripley v. International Rys., 8 App. Div. 2d 310, 188 N.Y.S.2d 62 (1059).

51. O'Neal, Molding the Corporate Form to Particular Business Situations: Optional Charter Clauses, 10 Vand. L. Rev. 1, 25-26 (1956).

52. 297 Mass. 398, 8 N.E.2d 895 (1937).

53. Id. at $412-13,8$ N.E.2d at 905 .

54. Id. at 413,8 N.E.2d at 905.

55. Id. at 417, 8 N.E.2d at 907. Similarly, the court in Everett v. Phillips, 288 N.Y. $227,234,43$ N.E.2d 18, 20 (1942), considered plaintiff's claim "against the background" of such a clause and placed heavy reliance on its presence.

56. Ewen v. Peoria \& E. Ry., 78 F. Supp. 312 (S.D.N.Y. 1948).

57. Id. at 316 .

58. Ibid. 
without regard to the presence of minority shareholders in the particular complaining "constituent unit."59

Ultimately, the failure of the traditional fiduciary rules in the parent-subsidiary context can be traced to the nostalgia which colored their promulgation, ${ }^{60}$ an attitude exemplified by a leading exponent of the revival of strict fiduciary principles in the early 1930's:

... the shareholder in the modern corporate situation has surrendered a set of definite rights for a set of indefinite expectations. The whole effect of the growth of the powers of directors and "control" has been steadily to diminish the number of things on which a shareholder can count; the number of demands which he can make with any assurance that they must be satisfied.1

Although this was indeed a concise description of the problem to which fiduciary doctrine was then, and continues to be, addressed, it does not follow that the proper task of the law is to apply more ironclad definitions of those same traditional "rights," clear on paper, but often irrelevant in practice. It would seem more fruitful to define fairness, instead, in terms of the shareholder's "expectations." "Indefinite" as they may be, these expectations should provide a useful source of standards of fairness in parent-subsidiary cases in two respects. In the first place, an attempt to gauge the fairness of a challenged transaction in terms of the expectations of the parties will focus attention on their entrance into the relationship - the only point in time when it is meaningful or relevant to look upon them as independent entities hammering out an agreement by means of the bargaining process. It is then that the terms of the relationship were set, and it is by reference to those terms that the fairness of the transaction in question ought to be judged.2 Secondly,

59. Id. at 317. However, Judge Hand only applied this test to decisions concerning the "actual conduct of the business" operations; to the "division of the income and expenses," he applied a different test, to the effect that plaintiffs had the burden of showing that an independent corporation would not have accepted the terms dictated by defendants.

60. A similar nostalgia for the nineteenth century economic world may be perceived in the formulation of the anti-trust laws. Their attempt to eradicate the external effeets of the concentration of corporate power concommitant with industrialization seerns analogous to the arm's length rules as they are applied to the internal government of the corporation. Cf. Arnold, The FolzLore of Cafitadisar 211 (1937). Nostalgia for the era of the individual entrepreneur may also be behind the law's obsession with the sharcholder's right to vote as a means of checking the power of corporate control groups. Cf. Alanning, sipra note 32 , and the remarks of Chayes, supra note 32 , at 40 :

The one explicit legal response in terms of structure to the bis corporation has nostalgically striven to reverse this process. It has consisted in efforts supported by legislation, judicial decision, and more than a dash of sloganeering, to restore meaning to the shareholder's vote.

It is unreal to rely on the shareholder constituency to keep corporate power responsible by the exercise of the franchise.... Ibid.

61. Berde \& Menans, The Modern Corporation and Private Property 277 (1932).

62. To proceed from such a base would not be without precedent, as far as the actual practice of courts is concerned. Indeed the emphasis of several courts on clauses authorizing 
the concept of the expectations of the parties provides the best medium for taking into doctrinal account the structural realities of the particular relationship presented in each case. The legal concept of expectations necessarily refers less to the intent of the parties in the subjective sense, than to the objective nature of the situation in which the parties are involved. ${ }^{03}$ In assessing the objective dimension of the parties' expectations, attention should be focused on the environment in which the original agreement was executed, ${ }^{04}$ and on the overall pattern of their relations since the commencement of the relationship. ${ }^{65}$ Fairness should be sought in the degree to which the particular

intercorporate dealings should be understood as a reference to the expectation of the parties. In Everett v. Phillips, for example, the court introduced its argument bearing on the authorization clause with reference to testimony by a leader of the Long Island controlgroup to the effect that the subsidiary in question was "formed for the purpose of finuncing and taking care of the various companies in which we were ... interested." Thus, the court continued, the control-group "invited the public to subscribe to the capital of the corporation which would be managed by directors in whose election no other stockholders would have any part, and those who might furnish the capital which these directors would manage were not left under any illusion that the directors, when acting for the corporntion, would be free from other interests which might prevent an unprejudiced excreise of judgment." 288 N.Y. 227, 233, 43 N.E.2d 18, 20 (1942). And the court in Even v. Pcaria $\& E . R y$. used the analogous purchase agreement emphasized in that case in an identical fashion - as a manifestation of the intended nature of the relationship between the linked corporations. 78 F. Supp. at 316.

63. Cf. Patterson, Constructive Conditions in Contracts, 42 Cotur. L. Rtv. 903, 91314 (1942); Corbin, Conditions in the Law of Contract, 28 Y MLE L.J. 739, 743-44 (1919).

64. Thus the court in Spiegel v. Beacon Participations, Inc. emphasized that the formation and function of the subsidiary in question in that case was "similar to many other such corporations created in connection with banks within the last fiftcen years with unlimited powers of investment and freedom from administrative supervision. 297 Mass. 398, 412, 8 N.E.2d 895, 905 (1937).

65. See the approach of Judge Hand, in analyzing the parties' intent in the Evucil caso: "When the 'Central' and the 'Peoria' declared their wish that both should 'be put under one management,' they could only have meant that the 'Peoria' should be treated as though it were a division of the 'Central' ... ." $78 \mathrm{~F}$. Supp. at 316 (emphasis added).

For a suggestion that fairness be defined in terms of the concept of expectations in an analogous context, see Wellington, Union Democracy and Fair Represcntation: Fideral Responsibility in a Federal System, 67 YaLE L.J. 1327, 1359-61 (1958). The problem discussed by Wellington is the definition of the duty of fairness owed non-tution employecs by a union selected by majority vote to represent all employees in collective bargaining. Wellington argues that the standards to be applied should be derived from the realities of collective bargaining practices, and concludes that the best medium for taking account of these practices in a given situation is the concept of expectations. His suggested standard would extend the objective dimension of the concept so as to base the test, not on the expectations of a reasonable man in the situation of the individual complainant in a particular case, but on the expectations of the "employee-community."

This question, whether or not to define expectations in terms of the situation of an individual complainant, is presented in a particularly acute fashion in the context of parentsubsidiary disputes. Its answer depends on a policy judgment, relevant to all types of claims of breach of corporate fiduciary duty, as to the general function of the shareholder's derivaltive action. If the action is viewed as a vehicle for policing corporate control-groups, then 
transaction, in the context of that pattern, conformed to the expectations of the parties, as of the time when the relationship was entered into, or perhaps, as of the last time when the complainant had a realistic chance of ending his participation therein. ${ }^{66}$

In measuring the degree to which the particular transaction challenged fits the parties' expectations, it is useful to distinguish between the result of the transaction, the structure defining the parties' relationship, and the management determinations by which the decision was reached. ${ }^{07}$ The result of the transaction in question should be compared with that of previous transactions between the linked corporations and with the allocation of proceeds and costs contemplated by their original agreement: was the allocation to be fixed

the equities of the particular shareholder's situation are irrelevant to the validity of the claim. All transactions detrimental to the subsidiary and inconsistent with the previous pattern of relations between the two corporations give rise to liability. If, however, the function of corporate fiduciary law is seen as providing a means of compensating undeserved losses by individual investors, then the situation of the particular complainant is crucial; if the changed course of dealing was initiated by the control-group before his purchase of stock, recovery would be barred on the theory that the expectations of a reasonable man buying stock at that time would not be inconsistent with the challenged transactions. (On this theory, the former owner would be viewed as having selected sale instead of suit as a remedy for the breach of duty to him.)

66. Where the transaction challenged does not comport with the expectations with which the parties entered into the parent-subsidiary relationship, as illuminated by the actualities of the relationship after its commencement, an authorization clause should not sustain the directors against a fiduciary claim. Such would appear the correct interpretation of Klopot v. Northrup, 131 Conn. 14, 37 A.2d 700 (1944). In that case, Chief Justice Araltbie held that an authorization clause did not justify the formation of a new corporation with the capital of the complaining subsidiary, where the plaintiff-minority shareholders were not afforded participation in the new corporation commensurate with that held in the dissolved subsidiary.

Failure to make a timely objection by way of suit to a changed course of dealings with the subsidiary should be treated as acquiescence on the part of the minority shareholders in the new position of the subsidiary. In the event that the remedy of sale was not realistically available to the plaintiff at the moment of the transfer of subsidiary control to the parent, due to a consequent drop in the market value of his shares, the rule of Perlman v. Feldman, 219 F.2d 173 (2d Cir. 1955), will provide an opportunity of recovery. In the unlikely event that control is purchased secretly or piecemeal by the new parent, no change in the expectations of non-controlling shareholders would accompany the change of control, and hence no shifts in policy detrimental to the subsidiary will be condoned.

67. Since the management of the parent corporation is in effective control of both the parent and the subsidiary, it is able to arrange the transaction as it wishes; hence it is futile to look to the formal decision-making procedures, as evidenced by the legal record of board meetings and the like, or to the degree to which "independent" directors or counsellors appear to have participated. Nevertheless, inquiry along such lines is frequently suggested as a cure for the confusion in fiduciary doctrine. See, e.g., Note, The Faimess Test of Corporate Contracts with Intercsted Direciors, 61 HARv. L. REv, 335, 340 (1943). Sce also proposal (2) advanced in 49 CoRNeLr L.Q. 520, 532 (1964). In the parent-subsidiary context, the only relevant aspect of the process by which the transaction was consummated is the business reasoning and the accounting determinations by which the challenged allocation figures were arrived at. 
or variable; if the latter, to what was it to be varied in proportion - the financial strength of the parent, ${ }^{68}$ the success of the subsidiary's particular line of business operations, ${ }^{60}$ the success of the system as a whole ${ }^{70}$ In putting the result of the transaction into its structural context, reference to the conceptual models of the contractual transaction and the statutory corporate structure should be avoided. Real factors should be the focus of concern : the actural structure of decisional power over the business operations affected - to what extent was the management of the subsidiary to be merged with that of the parent $;^{71}$ the functional relationship of the corporations - for example, was the subsidiary's role to insure the parent with a steady supply of raw materials or to provide the parent with financial backing for speculative velltures ?72 Finally, use of the expectations of the parties as a measure of fatirness should obviate all need to utilize burdens of proof as a means of avoiding analysis. Attention should only be paid to the allocation of the burden of proof when some genuine procedural function is served thereby. ${ }^{73}$

Case v. New York Central R.R. ${ }^{74}$ provides an opportunity to examine the application of the analysis outlined above to a particular parent-subsidiary dispute. Comparing the challenged transaction to an arm's length bargain, the majority reached the conclusion that the intercorporate agreement was unfair. ${ }^{75}$ However, the dissent, written by Judge Steuer, reflected a concern for the actual financial relationship between the two corporate entities. The subsidiary was analogized to a "landlord ... . whose only function has been to receive the rent which the Central guaranteed to [it.]" On the basis of this analysis the dissenters concluded that "the principle of equity by which it becomes entitled to [an outcome of paying no taxes and retaining all the savings] escapes us." "76

68. Such appears to have been the case in Everett v. Phillips, 288 N.Y. 227, 43 N.E.2d 18 (1942).

69. In Mardel Securities, Inc. v. Alexandria Gazette Corp., 183 F. Supp. 7 (E.D. Va, 1960), the claim of a complaining subsidiary newspaper company was granted by the court, where the profits from its own sales were siphoned off to the defendant parent.

70. Such appears to have been the case in Spiegel v. Beacon Participations, Inc., 298 Mass. 398, 8 N.E.2d 895 (1937).

71. The best treatment of this question is in Ewen v. Peoria \& E. Ry., $78 \mathrm{~F}$. Supp. 312, 316-17 (S.D.N.Y. 1948). See also Marony v. Applegate, 266 App. Div. 412, 421-22, 42 N.Y.S.2d 768, 779 (1943) ; Everett v. Phillips, 288 N.Y. 227, 233, 43 N.E.2d 18. 20 (1942). Cf. Chelrob, Inc. v. Barrett, 293 N.Y. 442, 452-53, 57 N.E.2d 825, 830 (1944).

72. See Spiegel v. Beacon Participations, Inc., 298 Mass. 398, 8 N.E.2d 895 (1937).

73. E.g., As when the defendant directors have sole access to corporate records relevant to the issues in the case. See notes $30 \& 31$ supra.

74. 19 App. Div. 2d 383, 243 N.Y.S.2d 620 (1963). The case has been the object of considerable law review commentary, all of it favorable to the decision of the Appellate Division. 77 Harv. L. Rev. 1142 (1964); 62 Mici. L. Rev. 1451 (1964); 49 Corneli L.Q. 520 (1964).

75. 19 App. Div. $2 d$ at 387,243 N.Y.S.2d at 625.

76. Id. at $388,391,243$ N.Y.S.2d at $625,627-28$. 
Both the analysis and the result of the dissenting opinion appear more satisfactory than the majority viewpoint. The question presented by the case is that which the minority opinion appears to be attempting to answer: are the expectations of the plaintiffs, as parties to the relationship of their corporation to the Central and its system, violated by the challenged agreement? The accuracy of the dissent's picture of that relationship is patent. The subsidiary, which occupies no office space and has no employees, has surrendered all control over its business and financial operations to the parent. ${ }^{77}$ Under the perpetual lease agreements signed at the inception of the relationship eight decades ago, the Central is the lessee of all the subsidiary's properties and railroad equipment; in return the subsidiary receives all operating expenses and forty percent of the gross earnings derived from the operations. ${ }^{78}$ These terms provide the minority shareholders in the subsidiary with a substantial and stable dividend income. ${ }^{79}$ In sum, the minority shareholders might be more realistically thought of as debenture holders, assured of a fixed return on their capital, regardless of the net profits of the Central system; in this posture they should have no reason to expect participation in any tax savings resulting only in an increase to net income of the integrated business. In light of these circumstances, the better conclusion of the case is that the expectations of the parties to this relationship were not violated by the challenged agreement, so as to justify court imposition of a more equal allocation. ${ }^{80}$

77. Brief for Plaintiffs-Appellants, p. 15.

78. 19 App. Div. 2d at 384, 243 N.Y.S.2d at 621 .

79. Brief for Plaintiffs-Appellants, pp. 3, 16. Over the past twenty-one years, the subsidiary recorded between $\$ 1.457$ and $\$ 3.029$ million before-tax profits.

80. Since the specific standards proposed in this Note are keyed to the structure of the parent-subsidiary relationship, it is probable that they would prove of little use in governing other contexts of self-dealing by control-groups. However, the criticisms of many of the present rules discussed herein apply to their use in other contexts as well, especially the emphasis on the allocation of the burden of proof or on subjective motivation, in terms which are imprecise and conceptually inappropriate, such as "honesty," "good faith," and "fraud." 